\author{
KAROL GREGORCZUK \\ ORCID: 0000-0002-2700-1578 \\ Uniwersytet Gdański
}

\title{
BIOPOLITYCZNE HORYZONTY - MIĘDZY BIOPOLITYKĄ TRADYCYJNĄ A BIOPOLITYKĄ NOWOCZESNĄ
}

\begin{abstract}
Abstrakt: Przedmiotem rozważań jest analiza podstawowych koncepcji biopolityki funkcjonujących we współczesnym dyskursie, kwestii krzyżowania dwóch wariantów biopolityczności, czyli biopolityki tradycyjnej oraz biopolityki nowoczesnej, jak również próba odnalezienia właściwych ich przejawów w szeroko rozumianej działalności społecznej. W ogólnym ujęciu biopolityka oznacza formę zarządzania przez ośrodki władzy procesami życia biologicznego przy ustaleniu normatywnych kryteriów życia i śmierci. Przegląd dostępnej literatury pokazuje, że tematyka ta doczekała się dość szerokich rozważań teoretycznych (na przykład M. Foucaulta, G. Agambena). Podejmując się refleksji badawczej zagadnienia biopolityki, chciałbym przyjąć wielowymiarową optykę obejmującą globalne procesy ekonomiczne, kulturowe i polityczne, kładąc szczególny nacisk na płaszczyznę normatywną wskazanych procesów.
\end{abstract}

Słowa kluczowe: biopolityka tradycyjna, biopolityka nowoczesna, życie, ciało, Foucault, Agamben

\section{WPROWADZENIE}

W aktualnym dyskursie politycznym często nawiązuje się do wybranych aspektów życia biologicznego, odnoszących się do procesów narodzin, kondycji zdrowotnej czy śmierci człowieka. Rządzący podejmują wszelkie niezbędne środki w celu objęcia ochroną różnych sfer indywidualnej i zbiorowej egzystencji. Zagadnienia prokreacji, zdrowia i choroby oraz umieralności nie są już wyłącznie przedmiotem indywidualnej troski, albowiem współcześnie stały się częścią przestrzeni publicznej, co w rezultacie doprowadziło do sytuacji, w której granice między prywatnym i publicznym się zatarły. Życie zaczęło zajmować centralną pozycję w zakresie planowania strategii rządzenia, w której w szczególny sposób odzwierciedla się relacja między wiedzą a władzą. Normalizowanie procesów biologicznych dotyczy dziś całych populacji ludzkich, dzięki czemu można włączyć 
i zaadaptować je do mechanizmów produkcji ekonomicznej, tym samym władza nad biologią ma służyć przede wszystkim pomnażaniu kapitału.

Decydujące znaczenie dla siły państwa ma współdziałanie trzech następujących elementów: ludność na stałym poziomie, suwerenna władza i określona przestrzeń terytorialna, które wymagają wdrożenia odpowiednich instrumentów ochrony. Niezbędne powinno być zagwarantowanie zbiorowego bezpieczeństwa w postaci utrzymania biologicznej substancji ludności, przetrwania organizacji państwowej i narodu, a także integralności terytorialnej i niezależności politycznej¹. Sprawowanie rządów w warunkach współczesnej biopolityki jest jednak ufundowane na nowym paradygmacie, zgodnie z którym podstawą funkcjonowania państwa jest już nie tyle terytorium, ile biologia obejmująca zbiorowe ciało ludzkiego gatunku. Wszelkie działania polityczne są ukierunkowane na zapewnienie wewnętrznej równowagi „,iała populacji” dzięki modelowaniu jego struktury, wykorzystując do tego różne wskaźniki demograficzne, ekonomiczne i statystyczne.

\section{DEFINICJA I PODSTAWOWE WYMIARY BIOPOLITYKI}

Polityka zorientowana na ludzkie życie w jego ujęciu biologicznym jest określana mianem biopolityki. Pojęcie powstało z połączenia dwóch wyrazów: „bio-” oraz „polityka”, co pozwala wyjaśnić jego główne aspekty semantyczne. Przedrostek „bio-” pochodzi od greckiego bíos oznaczającego „,̇ycie”, tworzy pierwszy człon wyrazów złożonych, który wskazuje na ich powiązanie znaczeniowe z życiem, procesami życiowymi czy żywym organizmem². W klasycznym ujęciu Arystotelesa państwo było traktowane jako wspólnota polityczna, ukształtowana w drodze naturalnego rozwoju, wywodząc się genetycznie z mniejszych ludzkich zbiorowości (rodzin, rodów, plemion). Organizacja państwowa „powstaje dla umożliwienia życia, a istnieje, aby życie było dobre", ma służyć dobru wspólnemu, rozumianemu jako harmonijne zaspokajanie potrzeb materialnych i duchowych społeczeństwa ${ }^{3}$. Według Stagiryty polityka oznaczała naukę o państwie traktowaną jako część filozofii praktycznej. Nowożytne koncepcje polityczne (na przykład T. Hobbesa, J. Locke'a, J.J. Rousseau) przyjęły natomiast odmienne założenie, zgodnie z którym społeczeństwo nie tworzy się w wyniku naturalnych procesów, ale jako rezultat umowy między członkami danej grupy, zatem ma ono charakter czysto konwencjonalny. W podanej perspektywie podstawowym zadaniem państwa jest ochrona przyrodzonych praw jednostki do życia, wolności, mienia itp. — zostaje tutaj uwypuklona indywidualistyczna koncepcja natury człowieka.

${ }^{1}$ Por. R. Zięba, J. Zając, Budowa zintegrowanego systemu bezpieczeństwa narodowego Polski. Ekspertyza, Warszawa 2010, s. 9.

2 Cyt. za: Stownik 100 tysięcy potrzebnych słów, red. J. Bralczyk, Warszawa 2005, s. 56.

3 Por. Arystoteles, Polityka, przeł. L. Piotrowicz, Warszawa 2004, ks. 1, rozdz. 1, 1252b-1253a. 
Truizmem jest twierdzenie, że od wieków życie stanowiło ważną płaszczyznę różnych działań politycznych. Warto zwrócić uwagę, że starożytni Grecy posługiwali się dwoma odrębnymi terminami do opisania życia, to jest bios i zoe ${ }^{4}$. W dosłownym rozumieniu biopolityka oznacza po prostu to samo co polityka zajmująca się życiem (bios + politike $)^{5}$. Centralną pozycję w stosunkach władzy przypisuje ona kategorii bios, czego przejawem jest postępująca ingerencja rządzących w wybrane aspekty ludzkiego życia. Francuski filozof M. Foucault wskazuje na oświeceniowy projekt jako właściwy koncept, który pozwolił państwu za pomocą środków medycznych normalizować, dyscyplinować i regulować życie społeczne, co miało przyczynić się do powstania biopolityki ${ }^{6}$.

Nowa refleksja naukowa (teoria doboru naturalnego K. Darwina) przyczyniła się do zasadniczej zmiany postrzegania istniejącej struktury społecznej, która miała być odzwierciedleniem zachodzących spontanicznie procesów biologicznych. Zbiorowe zachowania ludzi mogły zostać wyjaśnione, opierając się na mechanizmach doboru naturalnego, będącego jednym z podstawowych elementów determinujących zjawiska biologiczne, a zarazem jedną z głównych koncepcji teoretycznych w naukach o życiu ${ }^{7}$. Do wyjaśnienia aktualnych problemów politycznych, zarówno państwa, jak i prawa, pomocne było odwołanie się do konkretnych uwarunkowań przyrodniczych. Biopolityka to zjawisko złożone, które można za T. Lemke rozpatrywać w trzech perspektywach:

1. koncepcje naturalistyczne - życie jest traktowane jako podstawa polityki; zaliczają się do nich na przykład organicystyczne teorie państwa z początku XX wieku oraz teorie rasistowskie;

2. koncepcje politycystyczne — życie jest pojmowane jako przedmiot polityki, zajmuje się regulowaniem procesów życiowych; obejmują one dwa warianty: biopolitykę ekologiczną oraz biopolitykę technocentryczną;

3. koncepcje relacyjne i historyczne - życie staje się granicą działań podejmowanych przez człowieka, którą należy respektować albo przekroczyć; między innymi koncepcje M. Foucaulta, G. Agambena, M. Hardta i A. Negriego ${ }^{8}$.

${ }^{4}$ Termin zoe określa wszelkie bliżej nieokreślone życie, znajdujące się w ciągłym cyklu i niepodlegające śmierci, natomiast bíos oznacza życie jednostkowego organizmu, indywidualną egzystencję, kończącą się z chwilą śmierci.

5 T. Lemke, Biopolityka, przeł. T. Dominiak, Warszawa 2010, s. 7.

${ }^{6}$ J. Domaradzki, Genetyzacja społeczeństwa. Społeczne konsekwencje nowej genetyki, „Studia Socjologiczne" 2012, nr 2 (205), s. 8.

7 Por. A. Urbanek, Horyzonty intelektualne biologii wspótczesnej, „Kosmos” 1989, nr 48, s. 190.

8 Por. T. Lemke, op. cit., s. 9-13. 


\section{PODSTAWOWE KONCEPCJE BIOPOLITYKI}

\section{KONCEPCJE NATURALISTYCZNE BIOPOLITYKI}

Tradycyjna biopolityka przypisuje podstawową rolę funkcjonowaniu instytucji państwa i zamieszkującej jego terytorium populacji biologicznej. Jednym z wariantów tak rozumianej biopolityki są koncepcje naturalistyczne, w których przypadku działania inicjowane przez rządzących mają na celu wzmocnienie siły państwa, co dokona się dzięki zapewnieniu optymalnych warunków harmonijnego współżycia członków danej społeczności (populacji), traktowanej jako organiczna całość. Wszystkie instrumenty polityczne są tak naprawdę oparte na podstawowych prawach przyrody, gdyż prawidłowości dotyczące nauk biologicznych daje się prosto ekstrapolować na grunt nauk społeczno-politycznych. Teoria ewolucji Darwina została tu wykorzystana nie tylko do wyjaśnienia zmienności świata organicznego, lecz także wielu procesów społecznych, takich jak kształtowanie się form ustrojowych, powstanie prawa oraz geneza konfliktów zbrojnych ${ }^{9}$.

Za jednego z głównych przedstawicieli organicystycznej koncepcji państwa w perspektywie biopolitycznej uznawany jest szwedzki politolog R. Kjellén ${ }^{10}$. Jego zdaniem państwo miało tworzyć jednostkowy żywy organizm biologiczny, który do prawidłowego rozwoju potrzebuje właściwej przestrzeni geograficznej. Funkcje i zadania państwa były traktowane analogicznie jak czynności istot żywych uwarunkowane prawami biologii („,ciało państwowe”, „,instynkt biologiczny”, ,organiczne indywiduum”) ${ }^{11}$. Prawidłowy rozwój narodu zależał od posiadania szerokiej bazy terytorialnej, limitowanej naturalnymi granicami, z dostępem do morza czy dużych arterii komunikacyjnych. Wielkie mocarstwa są w pewnym sensie zobligowane do poszerzania swojego terytorium tak, aby tworzyło ono spójną ,przestrzeń życiową"12.

$\mathrm{Z}$ czasem zostały bardziej zaakcentowane elementy rasistowskie, mające być podstawą budowy jednolitego państwa narodowego w drodze konsekwentnie realizowanego programu ,inżynierii społecznej”. W latach trzydziestych XX wieku niemiecka nauka w dziedzinie badań rasowych była bardzo popularna na arenie międzynarodowej, zwłaszcza biorąc pod uwagę wdrażanie jej rozwiązań przez ustawodawstwo III Rzeszy ${ }^{13}$. Ideologia rasizmu przyjmowała założenie o istnie-

9 Por. A. Sylwestrzak, Historia doktryn politycznych i prawnych, Warszawa 2015, s. 271.

10 T. Lemke, op. cit., s. 17. Kjellén jako jeden z pierwszych posłużył się w swoich pracach pojęciem ,biopolityka”.

11 Por. A. Wolff-Powęska, Doktryna geopolityki w Niemczech, Poznań 1979, s. 112-113.

12 Ibidem, s. 113-114. Należy wyraźnie zaznaczyć, że Kjellén rozwinął wcześniejszą koncepcję F. Ratzla, który zaproponował biologiczną teorię państwa oraz jednocześnie był twórcą terminu Lebensraum (,przestrzeń życiowa”).

13 P. Madajczyk, Marzenie o narodzie doskonatym. Między biopolityka a etnopolityka, Warszawa 2017, s. 186. Tacy uczeni jak P. Broca i J.A. Gobineau stworzyli w XIX wieku podstawy „rasizmu naukowego” — teorii opisującej klasyfikację ludzkiej społeczności według kryteriów ra- 
niu odrębnych ras oraz powiązaniu cech fizycznych z właściwościami umysłowymi, moralnymi i kulturowymi, hierarchii rasowej, co powinno było znaleźć swoje odzwierciedlenie w rzeczywistości politycznej ${ }^{14}$. System polityczny III Rzeszy połączył pierwiastki rasistowskie i eugeniczne, dzięki czemu oczekiwano odrodzenia siły narodowej wspólnoty, wyzwolenia drzemiącego w niej potencjału, poprawienia poziomu życia itp. ${ }^{15}$ Realizacja biopolitycznego programu wymagała przy tym szerokiego zaangażowania przedstawicieli środowiska naukowego, którzy dostosowaliby swoje twierdzenia do nowych, narodowosocjalistycznych założeń. Połączenie teorii z praktyką zapewniło optymalne warunki do realizacji rasistowsko-eugenicznych postulatów na masową skalę, co znalazło swoje odzwierciedlenie w obowiązującym prawodawstwie III Rzeszy, na przykład w ustawie o zapobieganiu potomstwu obciążonego chorobą dziedziczną z 14 lipca 1933 roku, ustawach norymberskich z 15 września 1935 roku (ustawa o obywatelstwie Rzeszy, ustawa o ochronie krwi niemieckiej i niemieckiej czci oraz ustawa o barwach i fladze Rzeszy) czy rozporządzeniu o stosowaniu eutanazji u nieuleczalnie chorych antydatowanym na 1 września 1939 roku.

\section{KONCEPCJE POLITYCYSTYCZNE BIOPOLITYKI}

Podejście politycystyczne zaczęło się rozwijać od drugiej połowy XX wieku. Charakteryzuje się ono tym, że zasadniczym przedmiotem aktywności politycznej jest tutaj regulowanie określonych procesów życiowych ${ }^{16}$. O ile w koncepcjach naturalistycznych życie jest usytuowane „pod polityką”, tworząc właściwy punkt odniesienia wszelkich działań rządzących, o tyle koncepcje politycystyczne orientują raczej politykę ,,ponad życiem”, postrzegając ją w szerszej perspektywie społecznego praxis $^{17}$. Stanowisko politycystyczne charakteryzuje przyjęcie szerszego, globalnego horyzontu, wykraczającego poza granice poszczególnych państw i akcentujego szczególne napięcie między nowymi technologiami a naturą, tym samym jest ono zbieżne z niektórymi założeniami biopolityki nowoczesnej. W koncepcjach politycystycznych postrzega się biopolityczną panoramę w skali makro, w warunkach postępującej dynamiki przeobrażeń społeczno-ekonomicznych współczesnego świata.

Biopolityka ekologiczna ma rys bardziej konserwatywny, statyczny czy zachowawczy; proponuje wprowadzenie instrumentów mających na celu zabezpieczenie i zachowanie naturalnych podstaw życia biologicznego na Ziemi, wskazuje

sowych i wartościującej biologicznie poszczególne grupy rasowe. Podobne rozważania na temat historii eugeniki można znaleźć w S. Jones, Bóg, geny i przeznaczenie, przeł. M. Lewandowska, Warszawa 1997.

14 P. Madajczyk, op. cit., s. 220.

15 Por. ibidem.

16 Ibidem, s. 31.

17 Ibidem, s. 10. 
na potrzebę ustalenia warunków zrównoważonego korzystania z dostępnych zasobów przyrodniczych. Stanowisko ekologizmu zmierza do ochrony i poprawy jakości życia we wszelkich jego przejawach, czemu musi towarzyszyć kształtowanie świadomej troski o przyrodę, poczucia odpowiedzialności za różnorodność biologiczną, a także przeciwdziałanie degradacji środowiska naturalnego przez człowieka. Ekologizm jako ideologia zmierzająca do określenia poprawnych relacji między ludźmi a środowiskiem stopniowo wkracza do sfery prawno-politycznej, co skutkuje wdrożeniem proekologicznych rozwiązań do praktyki życia społecznego ${ }^{18}$. Wszelkie inicjatywy polityczne muszą mieć na względzie potrzebę zagwarantowania zharmonizowanej koegzystencji wszystkich istot żywych.

Odmienną koncepcją politycystyczną jest biopolityka technocentryczna, która akcentuje dynamikę zachodzących przemian społecznych w dobie postępu biotechnologii. Koncentrując się na rozwoju technologicznym i ekspansji gospodarczej, dostrzega się, że wszelkie procesy życiowe nie muszą być z góry zdeterminowane, mogą natomiast podlegać interwencji naukowo-technologicznej zgodnie $\mathrm{z}$ aktualnymi potrzebami społeczeństwa ${ }^{19}$. Mająca miejsce współcześnie modernizacja różnych instrumentów naukowo-technicznych, zwłaszcza w biotechnologii, dostosowuje do siebie społeczne formy produkcji i komunikacji, prowadząc do dominacji instrumentalnych form działania. Ingerencja biotechnologiczna w złożony i spontaniczny system życia organicznego powoduje zatarcie się kategorii tego, co zostało wyprodukowane, oraz tego, co powstało naturalnie ${ }^{20}$. Życie ludzkie przestało być postrzegane w ujęciu stacjonarnym jako zależne od niezmiennych praw biologii, gdyż może być ono obecnie poddawane dokładnej analizie i modyfikowane na poziomie mikrostruktur. Odczytanie języka DNA człowieka stało się momentem kluczowym nie tylko do zainicjowania badań teoretycznych, lecz także podjęcia szerokich działań politycznych na forum międzynarodowym (na przykład Powszechna deklaracja UNESCO w sprawie genomu ludzkiego i praw człowieka z dnia 11 listopada 1997 roku, Międzynarodowa deklaracja UNESCO w sprawie danych genetycznych z dnia 16 października 2003 roku, Powszechna deklaracja w sprawie bioetyki i praw człowieka z dnia 19 października 2005 roku).

\section{KONCEPCJE RELACYJNE I HISTORYCZNE BIOPOLITYKI}

Z kolei w ujęciu relacyjnym i historycznym biopolityka jest rozumiana jako granica działań politycznych, oddzielająca z jednej z strony to, co jest naturalne, określone odgórnie, niezmienne, od tego, co sztuczne, ulegające przekształceniu,

18 Por. R.A. Tokarczyk, Ekologizm inspiracją nowych nurtów myśli i systemów wartości, [w:] Ekologizm, red. M. Marczewska-Rytko, D. Maj, Lublin 2016, s. 14-16.

19 Por. T. Lemke, op. cit., s. 37.

20 J. Habermas, Przyszłość natury ludzkiej. Czy zmierzamy do engeniki liberalnej?, Warszawa 2003, s. 54-55. 
czysto konwencjonalne ${ }^{21}$. W swoich rozważaniach będę utożsamiał przedmiotowe koncepcje z tradycyjnie zorientowaną biopolityką, przy szczególnym uwzględnieniu funkcjonowania polityki w warunkach liberalnych systemów państw demokratycznych. Zdaniem francuskiego myśliciela Michela Foucaulta ludność zamieszkująca określone terytorium nie tworzy wcale polityczno-prawnej jedności, lecz samodzielną bytowość analizowaną za pomocą różnych wskaźników demograficznych, statystycznych lub epidemiologicznych ${ }^{22}$.

Osią zainteresowania biopolityki pozostają zjawiska masowe zachodzące na poziomie populacji — dzięki kontroli nad nią władza zmierza do zapewnienia globalnej równowagi oraz przeciwdziałania wewnętrznym zagrożeniom. Rządzący kierują swoją uwagę nie na poszczególnych obywateli zamieszkujących państwo, ale raczej na „urządzenie" biologicznego gatunku ludzkiego pojmowanego jako pewna całość ${ }^{23}$. Wykorzystywane instrumenty normalizacyjne są cennym narzędziem w ręku przedstawicieli władzy, jako że na podstawie danych populacyjnych można poddawać swoistej reglamentacji właściwości biologiczne „,iała społecznego". W nowych warunkach pojawia się szansa włączenia fenomenu życia w ramy odpowiednich norm i standardów, oddzielając życie od jego poszczególnych nosicieli i indywidualnych doświadczeń ${ }^{24}$.

Interesującym punktem rozważań przedstawionych przez francuskiego filozofa jest zwrócenie uwagi na zasadniczy punkt zwrotny, jaki nastąpił na przełomie XVIII i XIX wieku, gdy wyłoniła się nowa forma władzy nad życiem biologicznym ludzkiej zbiorowości — biopolityka/biowładza. Nie pojawiła się ona jako deus ex machina, jako że była rezultatem zachodzącej ewolucji władzy, która uprzednio miała ścisły związek $\mathrm{z}$ terytorium państwowym (władza suwerenna) lub ciałami jednostek (władza dyscyplinarna), współcześnie zaś sprawowana na poziomie populacji (biowładza). W czasach oświecenia wielu myślicieli zastanawiało się nad kwestią prawnego ograniczenia władzy politycznej, proponując w tym zakresie dwa rozwiązania. W pierwszym przypadku najpierw należy ustalić naturalne albo podstawowe prawa przynależne każdej jednostce, aby później można było określić jednoznaczne granice kompetencji instytucji rządowych. Niezbywalność praw człowieka wynikających jedynie z urodzenia się istotą ludzką, nie zaś z nadania ich przez jakiś zewnętrzny autorytet, limituje obszar dopuszczalnej ingerencji władzy. Drugie ujęcie koncentruje się raczej na analizie praktyki rządzenia, w tym jej faktycznych ograniczeń, jakie mogą wynikać z rozmaitych tradycji czy zwyczajów. Zastosowanie pewnych ograniczeń związanych z rządzeniem, przy odsepa-

21 T. Lemke, op. cit., s. 11.

22 Ibidem, s. 46.

23 A. Breczko, Podmiotowość prawna człowieka w warunkach postępu biotechnomedycznego, Białystok 2011, s. 24.

24 T. Lemke, Analityka biopolityki, rozważania o przeszłości i teraźniejszości spornego pojęcia „Praktyka Teoretyczna” 2011, nr 2-3, s. 18-19, http://www.praktykateoretyczna.pl/PT_nr23_2011_Biopolityka/ 01.lemke.pdf (dostęp: 10.02.2020). 
rowaniu działań pożytecznych albo zbędnych, może być przydatne do efektywnej realizacji zamierzonych celów politycznych w duchu utylitarystycznym ${ }^{25}$.

Foucault odczytuje pojęcie biopolityki w specyficzny sposób, podnosząc, iż współczesne nauki humanistyczne i przyrodnicze oraz ukute przez nie koncepcje ,normalności" nadają kierunek działaniom rządzących, definiując ich cele. Nie sposób jednakże ograniczać podanego zjawiska wyłącznie do pojawienia się nowych technologii czy wiązać go z obecnym kryzysem ekologicznym. Stanowi ono radykalne przeobrażenie dotychczasowego obszaru oddziaływania polityki, która od tej pory zmierza do osiągnięcia supremacji nad sferą ludzkiej biologii, przejmując kontrolę nad narodzinami i śmiercią, kondycją zdrowotną oraz długością ludzkiego życia ${ }^{26}$. Wspomniany autor posługuje się terminem „biopolityka” w trzech znaczeniach:

1. cezura historyczna w sposobie myślenia i działania politycznego;

2. podstawowy mechanizm w procesie pojawienia się nowoczesnego rasizmu;

3. instrument określający swego rodzaju sztukę rządzenia związaną z myślą liberalną 27.

Warto dodać, że granice między pojęciami „biopolityka” a „biowładza” nie zostały przez Foucaulta wyraźnie zakreślone. Jak wspomniano we wcześniejszych uwagach, przedmiotem nowo powstałej koncepcji polityki nie są ciała wyodrębnionych z ogółu jednostek, ale ciało określonej zbiorowości („,ciało społeczne”) ${ }^{28}$.

W ujęciu francuskiego filozofa myśl liberalna tworzy właściwe ramy funkcjonowania mechanizmów biopolityki, przyjmujące formę różnych instrumentów wiedzy i techniki w zakresie oddziaływania na cechy biologiczne populacji. Liberalne rządy doprowadziły od przeobrażenia pozycji jednostek, które były traktowane nie tylko przez pryzmat praw obywatelskich, ale też jako żywe istoty biologiczne. W świecie Zachodu doszło do stopniowego przeformułowania koncepcji „państwa terytorialnego” w „państwo populacyjne”, podlegające regułom wolnego rynku, ponieważ — jak napisał jeden z autorów — „tym lepiej rozwija się Widowisko Wcielone, w którym polityka i ekonomia stopiły się w jedną całość" 29 . Nie oznacza to wcale, że elementy władzy suwerennej czy władzy dyscyplinarnej zupełnie zanikły w nowych okolicznościach, jako że oba podlegają celom biopolityki/biowładzy i pozostają zakotwiczone w jej strukturze. Analiza Foucaulta zakłada, że rządomyślność jest obecnie bardziej wyrafinowaną formą władzy, która dąży do zarządzania całą populacją, natomiast osłabieniu ulega znaczenie władzy suwerennej zarządzającej terytorium oraz władzy dyscyplinarnej zarządzającej ciałami ${ }^{30}$. Specyfika rządów liberalnych polega na tym, że z jednej

25 M. Foucault, Narodziny biopolityki, Warszawa 2011, s. 62-64.

26 T. Lemke, Biopolityka..., s. 42-43.

27 Ibidem, s. 43-44.

28 Ibidem, s. 46.

29 K. Rutkowski, Ostatni pasaż: przepowieść o byciu byle-jakim, Gdańsk 2006, s. 228-229.

30 M. Czyżewski, Między panoptyzmem i „rządomyślnościa” — uwagi o kulturze naszych czasów, Warszawa 2009, s. 87, https://www.nck.pl/upload/archiwum_kw_files/artykuly/7._ma- 
strony gwarantują one jednostkowe prawa i wolności, ale z drugiej owe prawa i wolności muszą być nieustannie generowane przez rządzących według kalkulacji indywidualnych i zbiorowych potrzeb oraz przy zbilansowaniu ryzyka wzajemnych interesów. Liberalizm opiera się właśnie na pewnej kalkulacji ryzyka, zarazem pociągając $\mathrm{z}$ sobą ustanowienie mechanizmów bezpieczeństwa ${ }^{31}$.

Idea zaproponowana przez Foucaulta znalazła swoją kontynuację i twórcze rozwinięcie u innych myślicieli, między innymi u włoskiego filozofa Giorgia Agambena. W jego przekonaniu nowoczesność nie sytuuje się w opozycji względem zachodnioeuropejskiej tradycji, lecz stanowi raczej jej generalizację i radykalizację rozwijanych przez nią twierdzeń. Sposób, w jaki działa suwerenna władza, stwarza warunki do powstania ciała biopolitycznego. Wydarzenia mające miejsce w Europie w XX wieku są według tego autora prostą konsekwencją przyjętych założeń, których źródeł należy poszukiwać już w greckim antyku ${ }^{32}$. Agamben nawiązuje w tym miejscu do pojęcia homo sacer, oznaczającego właśnie człowieka wyjętego spod prawa, ograniczonego do swego fizycznego statusu i mogącego zostać bezkarnie zabitym. „Nagie życie” tworzy podstawę ciała politycznego, w którego ramach traktuje się kwestie życia i śmierci jako przedmiot suwerennej woli. Włoski myśliciel odwołuje się do kategorii obozu stanowiącego „ukryty paradygmat przestrzeni publicznej nowoczesności”, będącego miejscem systematycznej produkcji „nagiego życia”, które w dyktaturach przybiera formę obozów koncentracyjnych, a w demokracjach — więzień deportacyjnych i placówek dla uchodźców ${ }^{33}$.

Według niego od początku swego istnienia zachodnia tradycja ustrojowa zajmowała się wyłączaniem pewnych osób i grup poza obszar egzystencji politycznej, co ściśle wpisywało się w istotę działań rządzących. Ludzkie życie biologiczne staje się zatem przedmiotem wykluczenia ze sfery polityczności po to, aby można przejąć nad nim kontrolę, włączając jako „nagie życie” w obręb polityki. Produkowanie ciała biopolitycznego przez państwo jest pierwotną działalnością suwerennej władzy, która musi dla potwierdzenia swej legitymacji politycznej generować permanentny stan wyjątkowy. Państwo stanu wyjątkowego jednocześnie stwarza i definiuje przestrzeń, w ramach której porządek prawno-polityczny uzyskuje ostatecznie swój prawomocny charakter ${ }^{34}$. Agamben nawiązuje tutaj do myśli Carla Schmitta, że jedynie ten, kto może ustanowić stan wyjątkowy, jest uznawany za suwerena. W ten sposób władza ma wyłączne prawo do stosowania przemocy wobec osób wykluczonych, homines sacri, czyli ludzi pozbawionych

rek_czyzewski_-_miedzy_panoptyzmem_a_rzadomyslnoscia_-_uwagi_o_kulturze.pdf (dostęp: 27.06.2020).

31 M. Foucault, Security, Territory, Population, Lectures at the Collège de France, 1977-78, red. M. Senellart, przeł. G. Burchell, New York 2009, s. 498.

32 Ibidem, s. 64-65.

33 T. Lemke, Biopolityka..., s. 65-70.

34 Por. C. Mills, Biopolitics, London-New York 2018, s. 38-40. 
praw publicznych - status obywateli w ich przypadku zostaje zawieszony. „Nagie życie" tym samym zostaje zredukowane do samej egzystencji biologicznej, niemającej żadnych indywidualnych praw, aczkolwiek głęboko wpisanej w kontekst prawno-polityczny współczesnych państw demokratycznych.

Koncepcja Agambena jest oryginalną interpretacją zjawiska biopolityczności, jednak została ona opisana $\mathrm{w}$ duchu tradycyjnej biopolityki, związanej z rolą aparatu państwa i obowiązującego prawa, dychotomią reguła-wyjątek, życiem biologicznym ludzkiej populacji zapośredniczonym przez bieżący dyskurs polityczny. Przestrzeń stanu wyjątkowego stanowi dominujący paradygmat na Zachodzie, zarówno w systemach totalitarnych, jak i liberalno-demokratycznych. We współczesnych państwach następuje polaryzacja społeczeństw, polegająca na wyróżnieniu jednostek mających prawa polityczne oraz jednostek nieprzystosowanych, należących do mniejszości, mogących stanowić zagrożenie dla bezpieczeństwa (terrorystów, uchodźców, apatrydów). W celu realizacji określonej polityki przygotowuje się właściwe instrumenty normatywne, ukierunkowane na ugruntowanie stanu wyjątkowego, jak chociażby decyzja ramowa Rady UE z dnia 13 czerwca 2002 roku w sprawie zwalczania terroryzmu ${ }^{35}$, Konwencja Rady Europy o zapobieganiu terroryzmowi z dnia 16 maja 2005 roku $^{36}$, rezolucja Rady Bezpieczeństwa ONZ nr 2178 o konieczności penalizowania transgranicznych podróży w celach terrorystycznych ${ }^{37}$.

\section{BIOPOLITYKA TRADYCYJNA A BIOPOLITYKA NOWOCZESNA}

Tradycyjne ujęcie biopolityki odwołuje się do działalności organizacji państwowej, która wykorzystując instytucje publiczne, jak również techniki dyscyplinarne i bezpieczeństwa, sprawuje zwierzchnictwo nad populacją zamieszkującą dane terytorium. Model władzy suwerennej i dyscyplinarnej, jaki dominował w świecie Zachodu do XVIII wieku, stał się w kontekście nowych warunków ekonomii władzy anachroniczny, ponieważ centralną kategorią myślenia politycznego jest populacja, czyli ,»ciało społeczne«, które definiuje się poprzez właściwe sobie procesy i zjawiska, takie jak: wskaźnik urodzin i śmiertelności, poziom zdrowia, długość życia jednostek, wytwarzanie bogactw i ich cyrkulacji”38. Organizacja państwowa koncentruje się zatem na zarządzaniu zbiorem ludzi w celu

35 Decyzja ramowa Rady UE z 13 czerwca 2002 roku w sprawie zwalczania terroryzmu (2002/475/WSiSW), Dz.U. L 164 z 22.06.2002, s. 3.

${ }^{36}$ Konwencja Rady Europy o zapobieganiu terroryzmowi, sporządzona w Warszawie dnia 16 maja 2005 roku, Dz.U. z 2008 r. Nr 161, poz. 998.

37 Rezolucja Rady Bezpieczeństwa ONZ nr 2178 o konieczności penalizowania transgranicznych podróży w celach terrorystycznych z dnia 24 września 2017 roku, S/RES/2178 (2014).

38 Cyt. za: T. Lemke, Biopolityka..., s. 46. 
wykorzystania ich siły wytwórczej do pomnażania bogactwa, poprawy warunków materialnych i rozwoju technologii.

Tradycyjna biopolityka jest oparta na swoistej dychotomii życia i śmierci, w której ramach państwo ingeruje w naturalne procesy biologiczne, przyjmując określone kryteria życia ludzkiego ${ }^{39}$. Zarządzanie życiem ludności zostaje zoptymalizowane dzięki wykorzystywaniu przez rządzących danych demograficznych, epidemiologicznych oraz statystycznych, które pozwalają odpowiednio normalizować w skali populacji wskaźniki narodzin i zgonów, oczekiwaną długość życia, przypadki zachorowań, ludzką seksualność itp. Jak wskazuje Foucault, władza suwerenna sprawowała kontrolę nad danym terytorium, władza dyscyplinarna zaś porządkowała hierarchicznie przestrzeń do kontrolowania jednostek (szkoły, szpitale, więzienia), to jednak od XVIII wieku obie zostały podporządkowane celom biowładzy/biopolityki, koncentrującej się na zabezpieczaniu, kontrolowaniu i organizowaniu życia biologicznego ludzkiej populacji. Działania rządzących są od tej pory zorientowane raczej nie na pojęcie prawa, ale kategorię normy rozumianą jako właściwe kryterium standaryzacji zachowań ogółu jednostek w imię bezpieczeństwa (umożliwiające odróżnienie tego, co normalne, od tego, co za takie nie jest uznawane) albo mogą być przedstawione w perspektywie dychotomicznej reguła-wyjątek.

Jednym z kluczowych problemów biopolityki jest zagadnienie przestrzeni, w jakiej rządzący oddziałują na rządzonych. Państwo neoliberalne dysponuje określonymi technikami bezpieczeństwa, służącymi do formowania, kształtowania i modelowania zmiennych warunków środowiska, w jakiej funkcjonują jednostki.

Bezpieczeństwo urządza otoczenie pod kątem zdarzeń lub elementów możliwych, serii, którym trzeba będzie nadać pewien kształt, uwzględniając złożone i zmienne warunki. Odsyła ono do wymiaru czasu i przypadkowości, które należy wpisać w daną przestrzeń. Jest to chyba właśnie to, co nazywa się środowiskiem $[\ldots]^{40}$.

\section{Biowładza wytwarza społeczeństwo nowego typu, które}

zostawia duży margines swobody jednostkom, respektuje zasadę tolerancji wobec różnego rodzaju mniejszości, nie chce wpływać na uczestników gry, lecz jedynie na jej reguły, oraz interweniuje nie poprzez wewnętrzne podporządkowanie jednostek instytucjonalnemu planowi, ale uwzględniając ich własne środowisko społeczne ${ }^{41}$.

Zarządzanie procesami biologicznymi na poziomie populacji nie wymaga podejmowania przez instytucje publiczne bezpośrednich działań wobec jednostek, a raczej oddziaływania na różne sfery życia (rozrodczość, kondycja zdrowotna, umieralność) za pośrednictwem pewnych środków stymulujących.

39 Por. A. Breczko, op. cit., s. 24.

40 Cyt. za: M. Foucault, Bezpieczeństwo, terytorium, populacja: wykłady w Collège de France (1977-1978), przeł. M. Herer, Warszawa 2010, s. 45.

${ }^{41}$ Cyt. za: M. Czyżewski, op. cit., s. 88. 
Rozwój nowych technologii, genetyki i informatyki, jaki miał miejsce w ciągu ostatnich kilkudziesięciu lat, doprowadził do głębokich przemian dotyczących wzajemnych relacji między polityką a życiem, co było przyczynkiem do ukształtowania się nowoczesnej biopolityki. W dobie współczesnej rewolucji biotechnologicznej zaistniała możliwość technicznej ingerencji w wewnętrzną strukturę organizmów żywych, dzięki czemu uzyskano dostęp do informacji na temat ich cech dziedzicznych. Jürgen Habermas podkreśla, że

działanie biotechnologiczne różni się od technicznych ingerencji inżyniera stosunkiem „kolaboracji” z rozporządzalną naturą — albo „majstrowania” przy niej: „Gdy w grę wchodzi martwa materia, wytwórca jest jedynym działającym w stosunku do biernego materiału. Gdy w grę wchodzą organizmy, aktywność zderza się z aktywnością: technika biologiczna kolaboruje z samoczynnością aktywnego materiału, z systemem biologicznym, funkcjonującym z natury, do którego ma być włączony nowy determinant. [...] Akt techniczny ma tu formę interwencji, nie budowania"42.

Utworzenie specjalistycznych repozytoriów materiału biologicznego i danych służących do celów przyszłych badań biomedycznych odkrywa nowe oblicze współczesnej biopolityki. Takie wielkoskalowe bazy tworzą swoiste instrumentarium do zarządzania egzystencją biologiczną różnych organizmów żywych, zacierając stopniowo granice między tym, co należy do sfery biologii, a tym, co jest domeną polityki. W odróżnieniu od tradycyjnego podejścia w nowoczesnej, biopolitycznej konstelacji przedmiotem zainteresowania rządzących są nie tylko ludzie, lecz wszystkie istniejące elementy biotyczne. Symptomatyczne, że obecnie pojawiają się postulaty przypisania podmiotowości prawnej niektórym gatunkom zwierząt, na przykład uchwalenie Deklaracji praw waleni: wielorybów i delfinów na konferencji naukowej w Helsinkach 22 maja 2010 roku, zakaz przetrzymywania delfinów w niewoli do celów rozrywkowych jako mające status „osób niebędących ludźmi” (non-human person) w Indiach czy wydanie orzeczenia przez argentyński sąd w kwestii statusu osobowego orangutana w 2014 roku $^{43}$.

Dotychczasowe metody oddziaływania rządzących na strukturę danej populacji, w szczególności w sprawie reprodukcji, kondycji zdrowotnej oraz śmierci jednostek, uległy z upływem czasu przeobrażeniu, przyjmując formy, które są dostosowane do zmiennych warunków społecznych. Biopolityka w tradycyjnym rozumieniu akcentowała centralną pozycję państwa w sferze zarządzania zbiorowym ciałem społecznym, które jest tworzone przez osoby zamieszkujące dane terytorium, podlegające władzy zwierzchniej. Sztuka rządzenia przejawiała się

42 J. Habermas, op. cit., s. 56.

43 Por. Declaration of Rights for Cetaceans: Whales and Dolphins, Helsinki, 22 maja 2010 roku, https://www.cetaceanrights.org/ (dostęp: 28.06.2020); J. Krywko, Indie uznaty delfiny za ,osoby niebędace ludźmi”, https://wyborcza.pl/1,75400,15362542,Indie_uznaly_delfiny_za_osoby_ niebedace_ludzmi__WIDEO_.html (dostęp: 28.06.2020); T. Bawden, Orangutan inside Argentina zoo granted "non-human person rights" in landmark ruling, https:/www.independent.co.uk/news/ world/americas/sandra-the-orangutan-inside-argentina-zoo-granted-human-rights-in-landmark-ruling-9940202.html (dostęp: 28.06.2020). 
przede wszystkim w oddziaływaniu na populację za pomocą różnego typu wskaźników demograficznych w sposób zamierzony, mający służyć instrumentalnym celom państwa. Nowoczesna biopolityka dokonała zasadniczej zmiany tej optyki w taki sposób, że doszło do powstania policentryczności władzy, to znaczy osłabienia roli współczesnych państw na rzecz postępującej koegzystencji różnych ośrodków rządzenia, na przykład organizacji międzynarodowych, korporacji międzynarodowych, zorganizowanych ruchów społecznych. W pewnym sensie władza nad życiem i śmiercią przestała być wyłączną domeną państwa w tym sensie, że niektóre obszary z zakresu biomedycyny są przedmiotem deregulacji, stanowiąc legislacyjne terra incognita poddane władzy podmiotów prywatnych.

Współczesne badania biomedyczne, w których używa się zaawansowanych technologii informatycznych, obejmują nowe strategie biopolityczne, oparte na bardziej wydajnych niż dotychczas mechanizmach rządzenia. Tak zwana dekorporalizacja (decorporalization), będąca jednym z elementów nowoczesnej biopolityki, oznacza sposób zarządzania zdekomponowaną strukturą ciała w bankach materiału biologicznego, wyodrębnioną na różne systemy i kolekcje materiałów organicznych ${ }^{44}$. „Ciało biopolityczne” podlega w nowych warunkach procesowi decentralizacji czy depersonalizacji, pozostaje zintegrowane w obrębie zbioru zawierającego różnego typu materiały biologiczne, lecz zarazem przestaje mieć swe zindywidualizowane cechy, stanowiąc surowiec przeznaczony do dalszej obróbki. Rozwój infrastruktury banków materiału umożliwia wykreowanie obrazu ciała populacji, podlegającego społecznej kontroli wyznaczonych grup ekspertów, na przykład etyków, naukowców czy prawników, odpowiedzialnych za normalizację parametrów populacji.

Tak zwane biobanki reprezentują innowacyjne podejście w polityce zdrowotnej, ponieważ kładą szczególny nacisk na genetyczne podłoże warunków zdrowotnych, mogące kształtować określone style przyszłych zachowań jednostek czy zbiorowości, na przykład w kwestiach matrymonialnych, reprodukcyjnych bądź zawodowych. W ramach postępującego procesu dekorporalizacji istotne znaczenie mają informatyzacja (informationization) oraz molekularyzacja (molecularization), które prowadzą do uformowania się nowej infrastruktury biologicznej w postaci biobanków ${ }^{45}$. Wyjątkową rolę przy zorganizowaniu systemu biobankowania odegrał rozwój technologii informacyjnej, która pozwoliła naukowcom regularnie gromadzić i przetwarzać dane genetyczne, odczytane z zebranych w biobankach komórek, tkanek i narządów. Zaawansowana technologia komputerowa stała się doskonałym narzędziem służącym do analizy złożonego kompleksu danych, na przykład sekwencji danych kwasów nukleinowych i białek, co pozwoliło ich użyć do odczytania ludzkiego genomu w ramach programu Human Genome Project. Zarządzanie

${ }^{44}$ H. Gottweis, Biobanks in action: New strategies in the governance of life, [w:] Biobanks: Governance in Comparative Perspective, red. H. Gottweis, A. Petersen, London 2008, s. 26.

45 Ibidem. 
tego rodzaju bazą danych genetycznych wymaga dużego poziomu kooperacji w celu opracowania wspólnych procedur gromadzenia i organizowania informacji ${ }^{46}$.

Wprowadzenie do aktualnego dyskursu języka genetyki ma wpływ na relacje interpersonalne i funkcjonowanie instytucji społecznych, czemu towarzyszy koncepcja prywatyzacji ryzyka, która akcentuje indywidualną odpowiedzialność za własny stan zdrowia. Jakość życia jednostki zaczyna być bowiem uwarunkowana od osobistych starań i wyborów, między innymi aktywności fizycznej, odpowiedniej diety czy badań kontrolnych. W warunkach nowoczesnej biopolityki pojęcie ryzyka uległo swoistej transformacji, ponieważ o ile wcześniej (w kontekście tradycyjnej biopolityki) miało zewnętrzny charakter i było generowane głównie przez państwo, o tyle dzisiaj ryzyko zostaje umiejscowione w samej jednostce. Przywiązywanie dużej wagi do czynników genetycznych w kontekście etiologii chorób wymaga od każdego poniesienia odpowiedzialności za zdrowie własne i osób mu bliskich. Jednocześnie jednak ryzyko genetyczne może stanowić czynnik społecznych podziałów i wykluczenia oraz prowadzić do dyferencjacji grup według pewnych kryteriów uznawanych za wiążące normy społeczne. Owo ryzyko ma charakter konwencjonalny, nie jest odkrywane, lecz wytwarzane przez nowe ośrodki biowładzy ${ }^{47}$. Biologizm w istocie prowadzi do redukcji wszelkich zachodzących w rzeczywistości społecznej zjawisk do cech biologicznych.

\section{PODSUMOWANIE}

Życie przestało obecnie funkcjonować w powszechnej świadomości jako „bycie” (esse) zakotwiczone w przestrzeni transcendentalnej, a nabrało znaczenia bardziej utylitarnego czy praktycznego, dostosowanego do zbiorowych potrzeb $i$ indywidualnych preferencji. Wzrost liczby nowych technik znajdujących zastosowanie w naukach biomedycznych skłania do zastanowienia się nad potrzebą nowego odczytania pojęcia życia. Prowadzone na szeroką skalę działania biopolityczne pozwalają traktować poszczególne jednostki jako tworzące określoną zbiorowość, w pewnym sensie „ciało biopolityczne”. Z prowadzonymi pracami badawczymi wiążą się, jak wiadomo, duże nadzieje na poprawienie stanu zdrowia, ulepszenie jakości życia, zapewnienie warunków do indywidualnego rozwoju itp. Wiele realizowanych w dzisiejszych warunkach inicjatyw mających na celu wzmocnienie systemu zdrowia publicznego stanowi potwierdzenie tezy o prymacie ciała, które staje się właściwym punktem odniesienia preferowanych wartości, nie tylko społecznych, ale i politycznych. Należy zaznaczyć, że w nowej rzeczy-

46 D.S.T. Nicholl, An Introduction to Genetic Engineering, New York 2008, s. 153-156.

47 Por. J. Domaradzki, Genetyka, prywatyzacja ryzyka i polityka kozła ofiarnego, „Diametros” 2012, nr 32, s. 1-18, http://www.diametros.iphils.uj.edu.pl/serwis/pdf/diam32domaradzki.PDF (dostęp: 4.07.2019). 
wistości przeobrażeniu ulegnie samo zjawisko biopolityki - już dokonuje się znaczna zmiana jakościowa stosowanych przez rządzących metod. Pojęcia „,̇ycie” i „biopolityka” będą wymagały reinterpretacji, granica zaś między biologią a techniką, organizmem a robotem stanie się być może mniej wyrazista.

Analiza biopolityki tradycyjnej i biopolityki nowoczesnej pokazuje istotną przemianę, jaka dokonała się w podstawowych mechanizmach rządzenia w świecie Zachodu. Biopolityka tradycyjna dotyczy stanowisk akcentujących sferę imperium i dominium państwa, które za pomocą właściwych technik sprawuje zwierzchnictwo nad daną populacją zamieszkującą terytorium państwowe (koncepcje naturalistyczne biopolityki oraz koncepcje Foucaulta i Agambena). Gromadzenie danych statystycznych, demograficznych czy epidemiologicznych ma służyć pomnażaniu społecznego kapitału, dzięki czemu można zaangażować maksymalne siły w rozwój krajowej gospodarki. Z kolei biopolityka nowoczesna akcentuje koegzystencję różnych pozapaństwowych ośrodków rządzenia (organizacji międzynarodowych, korporacji międzynarodowych, zorganizowanych ruchów społecznych), przy czym w porównaniu z tradycyjną biopolityką nowe strategie biopolityczne opierają się na bardziej wydajnych mechanizmach rządzenia: dekorporalizacji, informatyzacji i molekularyzacji. W przeciwieństwie do klasycznego stanowiska, koncentrującego się na polityce ludzkiego życia, współcześnie coraz większe znaczenie ma uniwersalny bios, który obejmuje wszystkie elementy biotyczne (ludzkie, zwierzęce, roślinne). Rozwinięcie się nowych technologii informatycznych doprowadziło do przeobrażenia wymiarów biopolityczności, co skutkowało powstaniem zdekomponowanej, zdecentralizowanej struktury ciała populacji.

\title{
BIOPOLITICAL HORIZONS - BETWEEN TRADITIONAL BIOPOLITICS AND MODERN BIOPOLITICS
}

\author{
Summary
}

The subject of the article is an analysis of the general concept of biopolitics in contemporary discourse and the issues of crossing two aspects of two types of biopolitics: traditional biopolitics and modern biopolitics, as well as their function in a broader understanding of economic activity. Generally speaking, biopolitics means the form of management by power centers of control of biological processes, which establish normative levels of life and death. A literature review shows broad theoretical considerations (e.g. M. Foucault, G. Agamben). In this reflection on biopolitics, I would like to take into account the multidimensional optics, covering global economic, cultural, and political processes, with a special emphasis on the normative level of these processes. The theoretical analysis will focus on the issues of crossing two given types of biopolitics: traditional biopolitics and modern biopolitics, as well as trying to find changes in their broadly understood social activities.

Keywords: modern biopolitics, traditional biopolitics, life, body, Foucault, Agamben 


\section{BIBLIOGRAFIA}

Agamben G., Homo sacer: Suwerenna władza i nagie życie, Warszawa 2008.

Arystoteles, Polityka, przeł. L. Piotrowicz, Warszawa 2004.

Breczko A., Podmiotowość prawna człowieka w warunkach postępu biotechnomedycznego, Białystok 2011

Czyżewski M., Między panoptyzmem i „rzq̨domyślnościq” — uwagi o kulturze naszych czasów, Warszawa 2009.

Domaradzki J., Genetyzacja społeczeństwa. Społeczne konsekwencje nowej genetyki, „Studia Socjologiczne" 2012, nr 2 (205).

Foucault M., Bezpieczeństwo, terytorium, populacja: wyklady w Collège de France (1977-1978), przeł. M. Herer, Warszawa 2010.

Foucault M., Narodziny biopolityki, Warszawa 2011.

Foucault M., Security, Territory, Population, Lectures at the Collège de France, 1977-78, red. M. Senellart, przeł. G. Burchell, New York 2009.

Gottweis H., Biobanks in action: New strategies in the governance of life, [w:] Biobanks: Governance in Comparative Perspective, red. H. Gottweis, A. Petersen, London 2008.

Habermas J., Przyszłość natury ludzkiej. Czy zmierzamy do eugeniki liberalnej?, Warszawa 2003.

Lemke T., Analityka biopolityki, rozważania o przeszłości i teraźniejszości spornego pojęcia, „Praktyka Teoretyczna” 2011, nr 2-3, http://www.praktykateoretyczna.pl/PT_nr2-3_2011_Biopolityka/01.lemke.pdf (dostęp: 10.02.2020).

Lemke T., Biopolityka, przeł. T. Dominiak, Warszawa 2010.

Madajczyk P., Marzenie o narodzie doskonatym. Między biopolityka a etnopolityka, Warszawa 2017.

Mills C., Biopolitics, London-New York 2018.

Nicholl D.S.T., An Introduction to Genetic Engineering, New York 2008.

Olszewski H., Zmierczak M., Historia doktryn politycznych i prawnych, Poznań 1994.

Rutkowski K., Ostatni pasaż: przepowieść o byciu byle-jakim, Gdańsk 2006.

Sylwestrzak A., Historia doktryn politycznych i prawnych, Warszawa 2015.

Tokarczyk R.A., Ekologizm inspiracją nowych nurtów myśli i systemów wartości, [w:] Ekologizm, red. M. Marczewska-Rytko, D. Maj, Lublin 2016.

Tokarczuk R., Prawa narodzin, życia i śmierci, Warszawa 2012.

Urbanek A., Horyzonty intelektualne biologii współczesnej, „Kosmos” 1989, nr 48.

Wolff-Powęska A., Doktryna geopolityki w Niemczech, Poznań 1979.

Zięba R., Zając J., Budowa zintegrowanego systemu bezpieczeństwa narodowego Polski. Eksperty$z a$, Warszawa 2010. 